\title{
Technology Acceptance Model in the Usage of Regulation for Publication Media Services in the Ministry of Law and Human Rights
}

\author{
Edward James Sinaga ${ }^{1}$, Ahmad Sanusi $^{1}$, Hakki Fajriando ${ }^{1}$, Imam Lukito ${ }^{1}$, \\ Victorio Hariara Situmorang ${ }^{1}$, Rizki Bagus Prasetio ${ }^{1}$ \\ ${ }^{1}$ The Agency of Research and Development of Law and Human Rights of the Ministry of Law and Human Rights \\ of The Republic of Indonesia, Jakarta \\ Corresponding author: edsmy88@gmail.com
}

\begin{abstract}
Information technology currently influences the development of many areas of human life. The application of a technology system is expected to provide benefits and convenience in identifying and accessing information. This technology innovation was also carried out by the Ministry of Law and Human Rights. The peraturan.go.id webpage is a medium that functions as a means of disseminating all texts of the central level statutory regulations in accordance with the mandate of Law Number 12 of 2011 concerning the Formation of Laws and Regulations. Its existence is very beneficial for the community in providing information about the authentically guaranteed manuscript of law and regulations. Apart from that, it is also a means of facilitating public participation in the drafting of regulations as well as monitoring the performance of legislation annual target completion for regulations drafting. However, the webpage, currently managed by the Directorate General of Legislation, has seen a significantly decreasing number of visits. The 32,386 number of visitors of the webpage for December 2019 for example, was a decrease of $65.7 \%$ compared to 94,323 visitors in October 2019. Thus, it is important to comprehend the phenomenon through research to find the source of the problem that has resulted in a decrease in community visits to the site. This research aims to determine the relationship between variables in the Technology Acceptance Model (TAM) to determine the factors influencing users of the peraturan.go.id webpage service. The research was conducted with a mix of quantitative and qualitative methods. The quantitative data analysis used was the Structural Equation Model (SEM) using the AMOS application. Using SEM in the research allows the researcher to answer questions that are regressive or dimensional (i.e. measuring the dimensions contained in the concept). Data analysis was carried out in several stages to form the best model. The stages are carried out by confirmatory factor analysis, Full Model-Structural Equation Model Analysis, conducting hypothesis testing, and analysis of the influence of exogenous variables on endogenous variables. The data input used in this study is the variance/covariance matrix. Covariance matrices are considered to have the advantage of providing valid comparisons between different populations or samples, which is sometimes not possible when using a correlation matrix model. Distributing online questionnaires, 115 respondents were obtained to determine the application of TAM on the webpage. The results of this study indicate an actual simultaneous positive effect of 0.534 from the variable of ease of using the webpage in influencing the usage of the page. The variable of benefits of using the webpage has an actual positive effect of 0.768 in influencing the usage of the peraturan.go.id, and the positive attitude on the webpage also has an actual positive effect of 0.594 in influencing the actual use of it. Therefore, the conclusion that can be drawn is that the simultaneous benefit is more influential on the actual use of the webpage. It is recommended for the manager to increase the benefits of the webpage so that the actual use of the application can be increased.
\end{abstract}

Keywords: TAM (Technology Acceptance Model), regulation, media publication. 


\section{INTRODUCTION}

Information is a basic need for everyone as a form of personal development and social environment. Great Indonesian Languange Dictionary (KBBI) defines information as notification of news or news about something [1]. Then George R. Terry stated that information is important data that can provide useful or useful knowledge for the recipient [2]. Information is also defined as data that has been processed for a specific purpose to produce a decision (Anton M. Moeliono, 1990). Gordon B. Davis (1991) states that information is data that has been processed into a meaningful form for the recipient and is useful for current or future decision making [3]. The common thread from the opinion of experts above is that information is very important for society as beneficiaries and for public policymakers.

One form of information disclosure is manifested in the openness to public information. Public information in Law Number 14 of 2008 concerning Freedom of Information (UU KIP) is defined as information that is generated, stored, managed, sent and/or received by a public body related to state administrators and/or organizers and administration other public bodies that are under UU KIP and other information relating to the public interest. The public bodies in question are the executive, legislative, judiciary, and other bodies whose main functions and tasks are related to state administration [4]. One type of information that must be disseminated and not included in the exemption is the regulation as stated in article 18 paragraph (1) letter b of the KIP Law, namely provisions, regulatory decisions, circulars, or other forms of policy, whether binding or non-binding, binding inside or outside as well as the consideration of law enforcement agencies.

The peraturan.go.id webpage is one of the leading sectors in publications, especially the dissemination of statutory regulations as mandated by Law 12 of 2011 concerning the Formation of Legislation. Its existence is very beneficial for the community because it provides authenticallyguaranteed information regarding the regulatory text. The peraturan.go.id webpage is currently managed by the Directorate General of Legislation. However, the utilization of this website service that is owned by the Ministry of Law and Human Rights is still considered not optimal. This is evidenced by the low level of visits on that webpage. Based on the results of the analysis from SimilarWeb, a page that provides a tool to measure the level of popularity of a site, the number of visitors to peraturan.go.id from October to December 2019 has decreased significantly. This can be seen from the number of statistics on the visitors of the peraturan.go.id webpage in October 2019 which amounted to 94,323, while in December it was 32,386.

In practice, the text provided by this information provider website of laws and regulations must comply with the manuscript promulgated by the Ministry of Law and Human Rights. To make it easier for users of statutory regulations, the manuscript can be downloaded via the internet from the peraturan.go.id webpage. To ensure the validity of a statutory regulation text, research is conducted regarding the use of an authoritative website to provide a statutory regulation text.

\section{RESEARCH METHOD}

The research was conducted with a mix of quantitative and qualitative methods. The quantitative data analysis used was the Structural Equation Model (SEM) using the AMOS (Analysis of Moment Structures) application. The estimation model used is the maximum likelihood estimation because the amount of data is in the range of 100-200 pieces.

The population of this research is the users of the peraturan.go.id application who have used the application in 7 Provinces by distributing questionnaires online. There are 115 respondents who have filled out the questionnaire. In addition to distributing questionnaires, focus group discussions were also conducted.

The research used Technology Acceptance Model Theory. To explain individual behavior in the acceptance of information technology, Davis (1989) developed a TAM (Technology Acceptance Model) concept [5]. This concept is based on the theory of reasoned action (Theory of Reasoned Action) developed by Fishbein and Ajzen (1975) which explains that user behavior begins with belief, attitude, intention, and user behavior. The relationship between these components is explained in [6] Figure 1. 


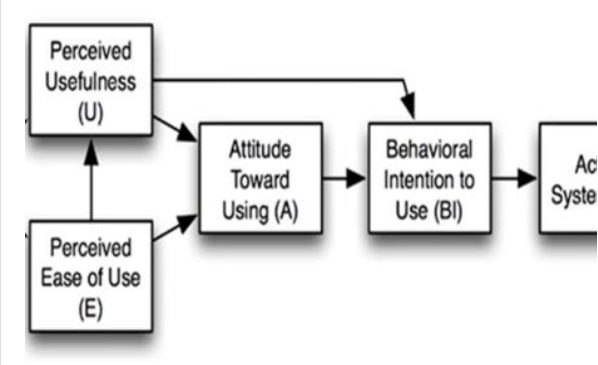

Fig.1. Technology Acceptance Model, Devis (1989)

The TAM concept has been shown to provide an empirical description of aspects of information technology user behavior. Iqbaria et. al. (1994) examined the factors that influence technology acceptance of microcomputers [7] and found that perceived ease of use had a direct effect on perceived usefulness.

Park (2009) [8] tested the interest in using elearning in South Korean universities using TAM. The results show that perceived usefulness and perceived ease of use do not have a direct correlation with student interest in using e-learning. This is because e-learning is considered something that is easy to use and the benefits of e-learning are well known to South Korean students. Conversely, these two variables have a direct effect on student attitudes towards e-learning. This attitude towards e-learning then influences the interest in using e-learning. In line with previous research, Pavlou (2003) [9] proved that perceived usefulness and ease of use had a significant effect on the interest in making transactions in e-commerce which ultimately led to actual usage.

Slightly different from the results of previous studies, I Putu Sugiartha Sanjaya (2005) [10] proved that perceived usefulness affects students 'and female students' interest in using the internet. However, this study found that perceived ease of use did not affect interest in using the internet. This is probably because the benefits of the internet to help performance are considered more important than ease of use. The construct indicators for ease of use are Ease of learning (easy to learn), Controllable, Clear Understable, and Flexible, Easy to becomming skillful, Easy to using [11].

The hypothesis proposed in this study:

$\mathrm{H}_{1}$ : Ease of use has a positive effect on the perceived usefulness of users in using the peraturan.go.id application.
$\mathrm{H}_{2}$ : Perceptions of benefits have a positive effect on the attitudes of users in using the peraturan.go.id application.

$\mathrm{H}_{3}$ : Ease of use has a positive effect on the attitudes of users in using the peraturan.go.id application.

$\mathrm{H}_{4}$ : The attitude to use the application has a positive effect on the intention to use the peraturan.go.id application.

\section{FINDINGS AND DISCUSSION}

\subsection{Confirmatory Factor Analysis Variable Laten.}

This confirmatory factor analysis is a measurement stage of the dimensions that form the latent variables in the research model. The latent variables or constructs used in this research model consist of 4 (four) variables contained in the Technology Acceptance Model (TAM), namely ease of use, perceived usefulness, behavioral intentions, and attitudes that will see their effect on the use of the peraturan.go.id webpage.

The purpose of confirmatory factor analysis is to test the validity of the dimensions forming each of the latent variables. Confirmatory factor analysis will be carried out on each latent variable as well as for the constructs of exogenous and endogenous variables.

The results of confirmatory factor analysis are measurements of the dimensions that form the latent variables in the research model. The results are summarized as in the table on the side. 
Table 1

Confirmatory Factor Analysis Variabel latent

\begin{tabular}{|c|c|c|}
\hline Goodness of fit measurement & Dimensi & Loading factor \\
\hline \multicolumn{3}{|l|}{ Easy Of Use (E) } \\
\hline \multirow[t]{6}{*}{ Prob $=0,000<0,05$} & E1 & 0,779 \\
\hline & E2 & 0,848 \\
\hline & E3 & 0,788 \\
\hline & E4 & 0,844 \\
\hline & E5 & 0,804 \\
\hline & E6 & 0,736 \\
\hline \multicolumn{3}{|l|}{ Perceived Usefulness (U) } \\
\hline \multirow[t]{6}{*}{ Prob $=0,000<0,05$} & U1 & 0,726 \\
\hline & $\mathrm{U} 2$ & 0,926 \\
\hline & $\mathrm{U} 3$ & 0,893 \\
\hline & $\mathrm{U} 4$ & 0,875 \\
\hline & U5 & 0,910 \\
\hline & U6 & 0,881 \\
\hline \multicolumn{3}{|l|}{ Attitude (A) } \\
\hline \multirow[t]{4}{*}{ Prob $=0,000<0,05$} & A1 & 0,830 \\
\hline & A2 & 0,858 \\
\hline & $\mathrm{A} 3$ & 0,904 \\
\hline & A4 & 0,862 \\
\hline \multicolumn{3}{|l|}{ Behavioral Intention (B) } \\
\hline \multirow[t]{3}{*}{ Prob $=0,000<0,05$} & B1 & 0,849 \\
\hline & B2 & 0,812 \\
\hline & B3 & 0,874 \\
\hline
\end{tabular}

\subsection{Analysis Full Equation Model}

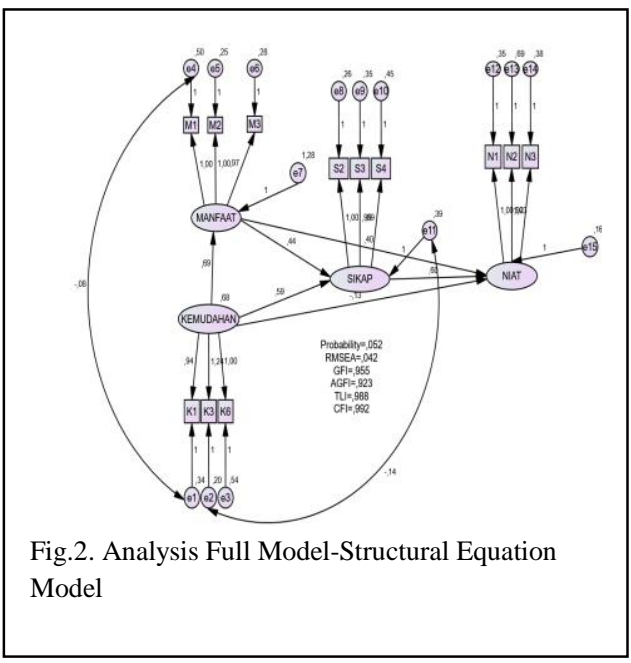

Analysis of the Full Model-Structural Equation Model As shown in Figure 2.

The test of the feasibility of the model shows that this model is in accordance with the data or fit the data used in the study, as seen in the following table 2.
Table 2

Structural Equation Model (SEM)

\begin{tabular}{|l|c|c|c|}
\hline \multicolumn{1}{|c|}{ Goodness of Fit Indeks } & Cut-off Value & Analysis Results & Model Evaluation \\
\hline Probability & $>=0,05$ & 0,052 & Good \\
\hline RMSEA & $<0,08$ & 0,042 & Good \\
\hline GFI & $>=90$ & 0,955 & Good \\
\hline AGFI & $>=90$ & 0,923 & Good \\
\hline TLI & $>=95$ & 0,988 & Good \\
\hline CFI & $>=95$ & 0,992 & Good \\
\hline
\end{tabular}

The results of the data processing analysis show that the constructs are used to form a study. In the analysis process, the full model SEM has met the predetermined goodness of fit criteria. The probability value in this analysis shows a value above the significance level of 0.052 ( $p>0.05$ ). This value indicates that there is no difference between the predicted covariance matrix and the estimated covariance matrix. Other goodness of fit measures also indicates good condition. Furthermore, the results of hypothesis testing are as shown in table 3.

Table 3

Hypothesis Testing Results

\begin{tabular}{|c|c|c|c|c|c|c|}
\hline & & & Estimate & S.E. & C.R. & $P$ \\
\hline Perceived Usefulness & $<-$ & Easy of Use & 687 & ,134 & 7,832 & 䋓米 \\
\hline Attitude & (2) & Perceived Usefulness &, 458 & ,057 & 8,723 & 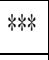 \\
\hline Attitude & K & Easy of Use &, 596 & 085 & 6,134 & 緙 \\
\hline Behavioral Intention & & Perceived Usefulness &, 405 & 058 & 6,906 & *蟏 \\
\hline Behavioral Intention & 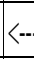 & Attitude &, 679 & 085 & 7,128 & 䗇 \\
\hline Behavioral Intention & 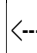 & Easy of Use & 132 & 078 & $-1,679$ & ,094 \\
\hline
\end{tabular}

\subsubsection{Hypothesis test 1}

The estimated parameter of the relationship between the ease of use with which the perceived usefulness of using the peraturan.go.id application is obtained at 0.687 . Testing the relationship between the two variables showing the value of C.R $=7.832$ with probability $=0.000(\mathrm{p}<0.05)$. So, it can be concluded that ease of use has a positive effect on the perceived usefulness of using the peraturan.go.id application, so the easier it is to use the peraturan.go.id application, the higher the benefits of using the peraturan.go.id application. Thus hypothesis 1 is accepted because there is a positive correlation (loading factor of 0.46 ) between the ease 
of using the peraturan.go.id application and the benefits of using the webpage.

\subsubsection{Hypothesis test 2}

The estimated parameter of the relationship between perceived usefulness and positive attitudes towards the peraturan.go.id application is obtained at 0.458 . Testing the relationship between the two variables showing the value of C.R $=8.723$ with probability $=0.000(\mathrm{p}<0.05)$. So, it can be concluded that the perceived usefulness had a positive effect on attitudes towards the peraturan.go.id application, so the more useful it is to use the peraturan.go.id application, the higher the attitude towards the webpage. Thus hypothesis 2 is accepted because there is a positive correlation (loading factor of 0.51 ) between the perceived usefulness and attitudes towards the webpage.

\subsubsection{Hypothesis test 3}

The estimation parameter of the relationship between ease of use and positive attitude towards it application is obtained at 0.596. Testing the relationship between the two variables showing the value of C.R $=6.134$ with probability $=0.000(\mathrm{p}$ $<0.05)$. So, it can be concluded that the ease of using the peraturan.go.id application has a positive effect on a positive attitude towards the peraturan.go.id application. In other words, the easier it is to use the peraturan.go.id application, the higher the positive attitude towards the webpage. Thus hypothesis 3 is accepted because there is a positive correlation (loading factor of 0.45 ) between the ease of using the peraturan.go.id application with a positive attitude towards webpage.

\subsubsection{Hypothesis test 4}

The estimation parameter of the relationship between positive attitudes towards behavioral intention to use the peraturan.go.id application is obtained by 0.679 . Testing the relationship between the two variables showing the value of C.R $=7,128$ with probability $=0,000(\mathrm{p}<0.05)$. So, it can be concluded that a positive attitude in the peraturan.go.id application has a positive effect on the behavioral intention to use the peraturan.go.id application, so that the more positive attitude on the webpage, the higher the behavioral intention to use the peraturan.go.id application. Thus hypothesis 4 is accepted because there is a positive correlation (loading factor of 0.60 ) between a positive attitude in the peraturan.go.id application and the behavioral intention to use the webpage.

\subsection{Analysis of the Effect of Exogenous Variables on Endogenous Variables}

This analysis is needed to determine the overall influence of exogenous variables on endogenous variables. This analysis was also carried out to determine the direct or indirect effect of exogenous variables on endogenous variables. The magnitude of the effect of each exogenous variable on the endogenous variable as a whole is shown in Table 4 as follows:

Table 4

Standardized Total Effects (Group number 1 - Default model)

\begin{tabular}{|l|r|r|r|r|}
\hline & Easy of Use & $\begin{array}{r}\text { Perceived } \\
\text { Usefulness }\end{array}$ & Attitude & $\begin{array}{r}\text { Behavioral } \\
\text { Intention }\end{array}$ \\
\hline Perceived Usefulness &, 462 &, 000 &, 000 &, 000 \\
\hline Attitude &, 082 &, 514 &, 000 &, 000 \\
\hline Behavioral Intention &, 534 &, 768 &, 594 &, 000 \\
\hline BI3 &, 452 &, 662 &, 508 &, 053 \\
\hline BI2 &, 428 &, 634 &, 482 &, 824 \\
\hline BI1 &, 457 &, 683 &, 525 &, 879 \\
\hline A4 &, 559 &, 422 &, 823 &, 000 \\
\hline A3 &, 592 &, 454 &, 865 &, 000 \\
\hline A2 &, 026 &, 462 &, 903 &, 000 \\
\hline E1 &, 811 &, 000 &, 000 &, 000 \\
\hline E3 &, 918 &, 000 &, 000 &, 000 \\
\hline E6 &, 447 &, 000 &, 000 &, 000 \\
\hline U3 &, 415 &, 920 &, 000 &, 000 \\
\hline U2 &, 420 &, 931 &, 000 &, 000 \\
\hline U1 &, 394 &, 873 &, 000 &, 000 \\
\hline
\end{tabular}

The table above shows the overall effect of the ease of using the peraturan.go.id application on the intention to use the peraturan.go.id application is 0.534, the effect of the benefit of using the peraturan.go.id application on the intention to use the peraturan.go.id application is 0.768 , and the effect of a positive attitude on the peraturan.go.id application on the intention to use the peraturan.go.id application is 0.594 . In conclusion, it can be ascertained that the benefits of using the peraturan.go.id application have the greatest influence on the intention to use the webpage. 
Then the direct effect appears in table 5 below:

Table 5

Standardized Direct Effects

(Group number 1 - Default model)

\begin{tabular}{|l|r|r|r|r|}
\hline & Easy of Use & $\begin{array}{r}\text { Perceived } \\
\text { Usefulness }\end{array}$ & Attitude & $\begin{array}{r}\text { Behavioral } \\
\text { Intention }\end{array}$ \\
\hline Perceived Usefulness &, 454 &, 000 &, 000 &, 000 \\
\hline Attitude &, 451 &, 524 &, 000 &, 000 \\
\hline Behavioral Intention &,- 093 &, 469 &, 594 &, 000 \\
\hline BI3 &, 000 &, 000 &, 000 &, 871 \\
\hline BI2 &, 000 &, 000 &, 000 &, 816 \\
\hline BI1 &, 000 &, 000 &, 000 &, 865 \\
\hline A4 &, 000 &, 000 &, 820 &, 000 \\
\hline A3 &, 000 &, 000 &, 867 &, 000 \\
\hline A2 &, 000 &, 000 &, 904 &, 000 \\
\hline E1 &, 803 &, 000 &, 000 &, 000 \\
\hline E3 &, 748 &, 000 &, 000 &, 000 \\
\hline E6 &, 000 &, 000 &, 000 &, 000 \\
\hline U3 &, 000 &, 924 &, 000 &, 000 \\
\hline U2 &, 000 &, 941 &, 000 &, 000 \\
\hline U1 &, 000 &, 875 &, 000 &, 000 \\
\hline
\end{tabular}

The table above indicates that the direct effect of the ease of using the peraturan.go.id application on the intention to use the peraturan.go.id application does not exist (no effect), which is equal to -0.093 , the direct effect of the benefits of the peraturan.go.id application on the intention to use the application peraturan.go.id is 0.469 while the direct effect of a positive attitude on the peraturan.go.id application is 0.594. The indirect effect is shown in table 6 below:

Table 6

Standardized Indirect Effects (Group number 1 - Default model)

\begin{tabular}{|l|r|r|r|r|}
\hline & Easy of Use & $\begin{array}{r}\text { Perceived } \\
\text { Usefulness }\end{array}$ & Attitude & $\begin{array}{r}\text { Behavioral } \\
\text { Intention }\end{array}$ \\
\hline Perceived Usefulness &, 000 &, 000 &, 000 &, 000 \\
\hline Attitude &, 252 &, 000 &, 000 &, 000 \\
\hline Behavioral Intention &, 638 &, 317 &, 000 &, 000 \\
\hline BI3 &, 419 &, 658 &, 524 &, 000 \\
\hline BI2 &, 423 &, 627 &, 485 &, 000 \\
\hline BI1 &, 457 &, 683 &, 531 &, 000 \\
\hline A4 &, 561 &, 425 &, 000 &, 000 \\
\hline A3 &, 583 &, 451 &, 000 &, 000 \\
\hline A2 &, 632 &, 472 &, 000 &, 000 \\
\hline E1 &, 814 &, 000 &, 000 &, 000 \\
\hline E3 &, 758 &, 000 &, 000 &, 000 \\
\hline E6 &, 000 &, 000 &, 000 &, 000 \\
\hline U3 &, 424 &, 000 &, 000 &, 000 \\
\hline U2 &, 431 &, 000 &, 000 &, 000 \\
\hline U1 &, 395 &, 000 &, 000 &, 000 \\
\hline
\end{tabular}

From the table above, it can be seen that the indirect effect of the ease of using the peraturan.go.id application on the intention to use the peraturan.go.id application is 0.638 , while the indirect effect of the benefits of the peraturan.go.id application on the intention to use the peraturan.go.id application is 0.317 .

\section{CONCLUSION}

From the analysis of the use of the peraturan.go.id webpage in public services with the application of the Technology Acceptance Model (TAM), namely by looking at the relationship between variables in the TAM, the following conclusions are obtained.

The overall effect of the ease of using the peraturan.go.id application on the intention to use the peraturan.go.id application is 0.534 , while the effect of the benefits of using the peraturan.go.id application on the intention to use the peraturan.go.id application is 0.768, and the influence of a positive attitude in the peraturan.go.id application the intention to use the peraturan.go.id application is 0.594 .

The ease of using the peraturan.go.id application has an effect on a positive attitude towards the peraturan.go.id application with a positive correlation of 0.45 . An information technology system that is considered easy to use tends to be accepted by users.

However, the ease of using the peraturan.go.id application does not have a direct effect on the intention to use the peraturan.go.id application (0,093). The ease of using the peraturan.go.id application must be followed by the benefits of using the peraturan.go.id application and from the benefits arise a positive attitude so that there is an intention to use the peraturan.go.id application.

The perceived usefulness the peraturan.go.id application affect a positive attitude towards the peraturan.go.id application with a positive correlation of 0.524 . The benefits of using the peraturan.go.id application that can be accepted by users of organizational activities to improve work performance and productivity will increase a positive attitude in using the peraturan.go.id application.

Meanwhile, a positive attitude in the peraturan.go.id application is related to the intention to use the peraturan.go.id application with a positive correlation of 0.60 . A positive attitude towards using 
the peraturan.go.id application is a mediator between personal beliefs and the intention to use the application.

So, it can be concluded that perceived usefulness has the greatest influence on the behavioral intention to use the peraturan.go.id application. It is recommended for the manager to increase the benefits of the peraturan.go.id webpage so that the actual use of the application can be increased.

\section{REFERENCES}

[1] Kemdikbud, "KBBI.Kemdikbud.go.id." .

[2] "https://pakarkomunikasi.com/pengertianinformasi-menurut-para-ahli.” .

[3] A. Saragih, "Memaknai Informasi Publik, sumber: https://aasaragih.wordpress.com."

[4] Republik Indonesia, Undang-Undang Nomor 14 tahun 2008 tentang Keterbukaan Informasi Publik. Jakarta, 2008.

[5] F. D. Davis, "Perceived usefulness, perceived ease of use, and user acceptance of information technology.," MIS $Q$., vol. 13, no. 3, pp. 319-339, 1989.

[6] P. A. M. W. et All, Aplikasi Model Tam (Technology Acceptance Model) Pada Perilaku Pengguna Instagram. .

[7] M. Iqbaria, “An Examination of Factor Contributing to Micro Computer Technology Acceptance," J. Inf. Syst. Q., vol. 13, no. 6, pp. 349-361, 1994.

[8] S. Y. Park, "An analysis of the technology acceptance model in understanding university students' behavioral intention to use e-learning.," Educ. Technol. Soc., vol. 12, no. 3, pp. 150-162, 2009.

[9] P. A. Pavlou, "Consumer acceptance of electronic commerce: integrating trust and risk with the technology acceptance model.," Int. J. Electron. Commer., vol. 7, no. 3, pp. 69-103, 2003.

[10] P. S. Sanjaya, "Pengaruh Rasa Manfaat dan Kemudahan Terhadap Minat Berperilaku (Behavioral Intention) Para Mahasiswa dan Mahasiswi Dalam Penggunaan Internet.," KINERJA, vol. 9, no. 2, pp. 113-122, 2005.

[11] Jogiyanto, Sistem Informasi Keperilakuan, Revisi. Yogyakarta: Andi Offset, 2007. 